\title{
The Effectiveness Research of Innovation and Entrepreneurship Education of College Students Based on the "Internet Plus" Era
}

\author{
Rui Ma ${ }^{1, a}$, Kai Wang ${ }^{2, b, *}$ \\ ${ }^{1}$ Beihua University ,Jilin, China \\ a1410770136@qq.com, b178971787@qq.com \\ ${ }^{*}$ Corresponding author: Kai Wang
}

Keywords: Internet plus, innovation and entrepreneurship education, effectiveness

\begin{abstract}
In 2015 China eighteenth CPC Central Committee fifth conference was held. On the conference some topics are pointed out: implementation of network strategy and "Internet plus" action plan, development of shared economy and implementation of national strategy for big data. College students are as national high level talents, college students' employment ability is related to the country's future and destiny. Therefore this article puts forward some ideas about how to enhance the effectiveness of innovation and entrepreneurship education of college students under the background of "Internet plus".

In the deepening of reform of college education it is a priority to improve the entrepreneurial ability of college students and to enhance the core competitiveness of college students. And the Internet has become a new innovation and entrepreneurship base for college students. But the innovative ability and consciousness of Chinese students is generally low. And how to enhance the effectiveness of innovation and entrepreneurship education of students should be considered in the era of "Internet plus" .
\end{abstract}

\section{The necessity of university students' innovation and Entrepreneurship}

It is an era of entrepreneurship. The innovation and entrepreneurship has become an important engine of today's social and economic development. It is the fundamental way to solve the employment problem in the society. It is an important means to promote national progress. Modern society provides a good economic environment and education conditions for college students. With the promotion of national spirit of "public entrepreneurship and innovation" it is combined with the domestic fast Internet market. A rich mythology was made and has attracted a large number of" after 95 "Internet entrepreneurs to join the army. High technology venture is also more popular.And more and more "after 95" began to try agricultural business and to learn to use their own advanced knowledge nurturing homeland. In 2016 the number of college graduates hit a high record to reach $7,650,000$. However, college students' entrepreneurial success rate is not optimistic. Recently, the Internet has launched an investigation on the entrepreneurship of college students. And a social survey of "the students in your eyes" has started simultaneously. The target of this survey is to reflect the original understanding of the innovation of the college students. At the same time it is to compare the ideas of college students and the social views on college students'. The new view of entrepreneurship, the new perspectives and new demand of college students are shown. No investigation, no right to speak. To what extent College students have reached about entrepreneurship the data would tell you clearly.

In the author's opinion, now the entrepreneurship is like the threshold of University which is easy to enter but is difficult to graduate. For the college students who is thinking fashion and to accept new things and new concept entrepreneurship and innovation is more like a spring seat triggered at any moment. At the beginning speed is fast but quickly it is slow down quite obviously. At the beginning if the speed is faster the degree of destruction of landing will be greater. Finally, giving a data, now the success rate of college students' entrepreneurship is $2 \%-3 \%$. Therefore, it is certain that the creative and entrepreneurial passion is far from enough. This paper combines the characteristics of innovation and entrepreneurship education with "Internet plus" era of colleges and 
universities, puts forward some thinking to enhance the effectiveness of education innovation and entrepreneurship of students.

\section{2. "The combination of "Internet plus" and innovation and entrepreneurship of College Students}

As one of the most advanced productive forces, with the development of "Internet plus" policy step by step, the Internet business will become a major trend in the development of our society. In addition to the wide development of space, attractive salary and welfare, it has a close relationship with the Internet industry humanization operation style. "after 95" are as the Internet aborigines, the flexible and humane atmosphere of Internet industry has just cater to the free and open personality of the generation. Therefore, it is not difficult to understand that the Internet has become the most popular entrepreneurial projects. The latest report shows that, in addition to job seekers (52\%), the deep study (21.43\%), the independent venture (15.31\%) has become a new way of employment of college students. Nearly half of the "after 95" have started to focus entrepreneurship on overseas online shopping, O2O, self-media and other emerging Internet projects. So Internet has become an important media and means for independent venture of college students.

2.1what is the "Internet plus"

$\mathrm{Li}$ Keqiang puts forward the "Internet plus" is actually new situation of Internet development under the new form of 2.0. It is the new evolution of the Internet formats under the knowledge society driven by innovation of 2.0. Before the Internet is just as an external tool. But today's Internet has been the core engine to promote social innovation. A 40 billion investment and entrepreneurship fund has set up to guide new industry. To integrate more funds, to innovate industry and to promote innovation and entrepreneurship, fully stimulate the market and social vitality the new normal era is entered driven by innovation development of 2.0. The "plus" of "Internet plus" means the traditional industry. "Internet plus" mode is from comprehensive application of the third industry, such as the formation of Internet banking, Internet traffic, internet medical, Internet Education and other new formats. And it is penetration to the first and the second industry. Because of this, the Internet provides a broader entrepreneurial platform for college students to start a business.

2.2 College Students' innovation and entrepreneurship characteristics and advantages under the background of"Internet plus"

With the development of internet economy it has the advantage of less investment and less resource. It has become a good opportunity for the entrepreneurship of college students. Because of this reason the internet business has become a new way for college students to make entrepreneurship and a new entrepreneurial opportunities. A large number of physical stores costs has canceled from online business stores. The virtual store has replaced the traditional "appearance". And it is also flexible to choose office location, even in the bedroom or in the laboratory. The cost of rental shops is eliminated. Internet Entrepreneurship has no high requirement for social experience and capital requirements. It is an ideal way to start a business for the college students who is just graduated. Under the Internet there are many kinds of new marketing approach, such as internet shop, micro business and APP, which are new modes of new era internet entrepreneurship. In addition, the Internet has broken the time and space constraints with flexible working hours. College students in the process of entrepreneurship are also to complete their academic tasks. So the main use of spare time of night and rest days are more abundant.

\section{How to enhance the effectiveness of education of College Students' innovation and entrepreneurship under the background of "Internet plus"}

Although with the excellent network business situation there are many advantages. But through the investigation on the students' network business college internet business is also facing some difficulties. Such as insufficient entrepreneurship preparatory work, no market survey,weak entrepreneurial risk awareness, lack of network business knowledge and skills. According to these 
difficulties it is necessary to strengthen the innovation and entrepreneurship education under the background of "Internet plus". Specific method is as follows:

3.1 Focus on market research and to guide students to choose the correct network entrepreneurial projects. According to their own interests and hobbies, to define the market direction and to understand the corresponding market environment and find the characteristics of consumer groups. It is important to make reasonable positioning of their own advantages, to make the comparison of the defects and shortcomings of competitors in order to establish their own network service brand as the starting point. Planning of accurate network marketing program and to strive for innovation to make the entrepreneurial content more attractive.

3.2 Strengthening the training of network entrepreneurial skills. [Professional knowledge of Network Entrepreneurship should be added to the courses, while cultivating students' good psychological quality. So that it can be the courage to have setbacks in the entrepreneurial period. Focus on training students' leadership planning ability to make their own management team. It is the premise and foundation to do a good job of network innovation and entrepreneurship.

3.3Strengthening education of risk awareness. To guide students to establish financial risk awareness, to strengthen financial management; to assist the students to make operation management program for the venture capital, to guarantee the income and expenditure are documented and to guarantee the feasibility scheme of the network. It is to lay the foundation for the later work.

\section{Conclusion}

In the form of new internet college students are curious about new things. And they have a unique judgment and quickly speed of understanding in the future. More and more college students have realized that entrepreneurship is an important way to realize the value of life. Around the project of Internet innovation and entrepreneurship has become an ecological thing. Universities should actively guide and encourage the development of personality and encourage students to independent innovation in daily education. It is to cultivate students' Internet thinking with combined with the new situation of social development and the needs of college students. To cultivate the ability of knowing and solving problem, to guide students to be qualified "Internet plus" in the era of entrepreneurs.

\section{Acknowledgements}

This stage research achievement was financially supported by 2016 Jilin Provincial Social Scien ce Project, China (Grant No.PS 1619-2).

\section{Reference}

[1], Sui Ping, [J]. application of the cultivation of innovative talents of innovative education and practice, based on Chinese, higher education research, 201308

[2], Feng Lin, to build innovative education platform to enhance the ability of innovation and practice of college students; [J]., chemical higher education, 20114

[3], Qiao Yuting; Bao Qinglong; Zeng Li Internet plus "era of higher education management model innovation and Enlightenment of higher education in 201512

[4], Wan Liyong; Kang Cuiping, Internet plus a customer education: Construction of innovation and entrepreneurship education in Colleges and universities in the new ecological development of [J]. education in 20164

[5], Liu Yan, innovation and entrepreneurship education and the depth of the integration of professional education [J]. China University Teaching 2014-11-15

[6], Liu Wei, China's current situation of innovation and entrepreneurship education research and 
policy recommendations -- Based on the sampling of 8 universities, [J].; education science, 201412 [7], Zhang He, innovation and entrepreneurship education in Colleges and Universities: mechanism, path, mode, [J], Journal of the National Institute of education administration, 201410 